\title{
EKSTRAKSI KOMPONEN ANTIOKSIDAN TEPUNG KOMPOSIT BERBASIS PISANG GOROHO DAN LABU KUNING DENGAN BANTUAN ULTRASONIK
}

\author{
Imanuel M. Pasanda $^{1 *}$, Edi Suryanto ${ }^{2}$ dan Adisti A. Rumayar ${ }^{3}$ \\ ${ }^{1}$ Program Studi Ilmu Pangan, Program Pascasarjana, Universitas Sam Ratulangi \\ ${ }^{2}$ Program Studi Kimia, Fakultas Matematika dan Ilmu Pengetahuan Alam Universitas Sam Ratulangi \\ ${ }^{3}$ Fakultas Kesehatan Masyarakat, Universitas Sam Ratulangi \\ Jl. Kampus Unsrat, Kleak, Manado 95115 Sulawesi Utara
}

\begin{abstract}
ABSTRAK
Tanaman-tanaman lokal yang mengandung antioksidan, yaitu pisang goroho dan labu kuning, digunakan untuk mengembangkan tepung komposit. Penelitian dilakukan untuk mengevaluasi efek pencampuran tepung pisang goroho dengan tepung labu kuning terhadap kandungan fitokimia antioksidan (total fenolik dan beta karoten) dan kapasitas antioksidan (kemampuan menangkal radikal DPPH dan daya reduksi) dari tepung komposit yang dihasilkan dengan menggunakan bantuan ultrasonik pada tahapan ekstraksi. Formulasi tepung komposit yang digunakan (tepung pisang goroho:tepung labu kuning) adalah 75:25, 50:50, dan 25:75. Kandungan total fenolik tepung komposit berkisar antara 98,2- 78,8 mg/kg GAE, dan kandungan beta karoten tepung komposit berkisar antara 186,1-497,8 $\mathrm{\mu g} / \mathrm{g}$. Hasil penelitian menunjukkaan peningkatan kandungan fitokimia antioksidan dan kapasitas antioksidan pada tepung komposit terjadi dengan meningkatnya proporsi tepung labu kuning.
\end{abstract}

Kata kunci: Antioksidan, tepung komposit, pisang goroho, labu kuning

\begin{abstract}
Locally grown crops with antioxidant content i.e. goroho plantain dan yellow pumpkin were used to develop composite flours. The current study aimed to investigate the effect of mixing goroho plantain flour with yellow pumpkin flour on phytochemical content (total phenolic and beta carotene) and antioxidant capacity (DPPH assay and reducing power assay) of developed composite flours, assisted by ultrasound in the extraction step. Flour formulations (goroho plantain flour: yellow pumpkin flour) used were 75:25, 50:50, and 25:75. Total phenolic content of composite flours ranged from 98.2-178.8 mg/kg GAE, and beta carotene content of composite flours ranged from $186,1-497,8 \mu \mathrm{g} / \mathrm{g}$. The study showed that increased in phytochemical antioxidant content and antioxidant capacity of composite flours were due to increasing in yellow pumpkin flour proportion in composite flour.
\end{abstract}

Keywords: Antioxidant, composite flour, goroho plantain, yellow pumpkin

\section{PENDAHULUAN}

Metabolisme oksidatif yang terjadi dalam sel akan menghasilkan sejumlah kecil spesies oksigen reaktif seperti radikal-radikal superoksida, radikal-radikal hidroksil, hidrogen peroksida dan radikal-radikal peroksida. Spesiesspesies kimia tersebut tidak stabil dan dapat bereaksi dengan cepat dengan senyawa lain yang ada dalam tubuh sehingga menyebabkan kerusakan pada sel atau jaringan. Penelitian bahkan telah menunjukkan adanya hubungan antara terakumulasinya radikal-radikal bebas dalam tubuh dengan penyakit-penyakit seperti kanker, aterosklerosis, hipertensi, dan radang sendi (Carocho \& Ferreira, 2013).
Antioksidan adalah senyawa yang dapat mencegah atau memperlambat kerusakan oksidatif yang disebabkan oleh oksidatoroksidator. Para peneliti epidemiologi menyatakan bahwa makanan-makanan yang mengandung antioksidan memiliki efek perlindungan potensial terhadap kerusakan yang disebabkan oleh spesiesspesies oksigen reaktif. Banyak penyakit kronis dapat dicegah dan dihambat perkembangannya dengan meningkatkan pertahanan antioksidan alami tubuh atau dengan menyuplai antioksidan melalui makanan (Mehta dkk., 2015). Menurut Liu (2003), suplai antioksidan yang beragam melalui makanan memberikan manfaat kesehatan karena kombinasi dari efek aditif dan sinergis. Ketertarikan pada peran antioksidan dalam

\footnotetext{
"Korespondensi :

Telepon: +62 813-4383-6535

Email: medy.pasanda@gmail.com

DOI: https://doi.org/10.35799/cp.12.1.2019.27300
} 
kesehatan manusia telah mendorong para peneliti untuk mengevaluasi kandungan antioksidan pada buahan dan sayuran. Keragaman kimia dari antioksidan menyebabkan bervariasinya teknik pemisahan dan pengukuran antioksidan pada matriks biologi/pangan. Suhu, polaritas pelarut, lama waktu ekstraksi dan metode ekstraksi sangat mempengaruhi komposisi dan sifat antioksidan dari ekstrak. Selanjutnya, ekstraksi dengan teknik konvensional, seperti maserasi, adalah proses yang membutuhkan waktu yang lama dan pelarut yang banyak. Penggunaan teknik-teknik modern, seperti ekstraksi dengan bantuan gelombang mikro atau ultrasonik dilaporkan dapat meningkatkan efisiensi dan selektifitas proses ekstraksi (Falleh dkk., 2012).

Pisang goroho dan labu kuning adalah tanaman-tanaman lokal yang mengandung antioksidan (Suryanto dkk., 2011, Gumolung dkk., 2013). Pisang goroho telah lama dijadikan sebagai sumber makanan dengan mengolahnya menjadi pisang rebus atau pisang goreng (Turang, 2017). Selain itu, pisang goroho dapat juga diolah menjadi tepung (Nurali dkk., 2012). Labu kuning dikonsumsi sebagai sayur atau dapat diolah menjadi tepung. Tepung pisang goroho dan tepung labu dapat dicampurkan untuk menghasilkan tepung komposit (Pasanda dkk., 2019).

Berdasarkan penelusuran pustaka belum ada penelitian yang menggunakan bantuan ultrasonik untuk proses ekstraksi dan penentuan kapasitas antioksidan dari tepung komposit yang dihasilkan dari tepung pisang goroho dan tepung labu kuning. Penelitian ini dilakukan untuk mengevaluasi efek pencampuran dari tepung pisang goroho dan tepung labu kuning pada beberapa perbandingan terhadap kandungan antioksidan dan kapasitas antioksidan tepung komposit yang dihasilkan dengan menggunakan sonikator dalam proses ekstraksi.

\section{BAHAN DAN METODE}

\section{Bahan dan alat}

Alat-alat yang digunakan dalam penelitian antara lain: pisau, blender, oven, alat penggiling, ayakan 80 mesh, alat-alat gelas, timbangan analitik, alat sentrigugasi, sonikator, dan spektrofotometer. Bahan yang digunakan dalam penelitian ini yaitu pisang goroho putih pada tingkat kematangan 80\% (7-10 hari sebelum panen) dan labu kuning jenis bokor pada tingkat kematangan 7 hari sebelum panen. Bahan-bahan utama yang digunakan dalam analisa: aquades, etanol, petroleum eter, reagen Folin Ciocalteu, asam galat, DPPH, feri klorida $\left(\mathrm{FeCl}_{3}\right)$, kalium ferisianida, dan buffer fosfat.

\section{Preparasi sampel dan penepungan}

Pembuatan tepung pisang goroho menggunakan metode yang dilakukan oleh Suryanto dkk. (2018). Pisang dikukus selama 15 menit pada suhu $80^{\circ} \mathrm{C}$, dikupas dan dipotongpotong dengan ketebalan $2 \mathrm{~mm}$. Potongan pisang dikeringkan dalam oven pada suhu $50^{\circ} \mathrm{C}$ selama 9 jam. Setelah kering, potongan-potongan pisang dihaluskan dan diayak menggunakan ayakan 80 mesh. Tepung pisang goroho disimpan dalam kantong plastik kedap udara untuk perlakuan selanjutnya.

Pembuatan tepung labu kuning menggunakan metode yang dilakukan oleh Prabasini dkk. (2013) dengan modifikasi. Labu kuning dicuci, dipotong menjadi beberapa bagian dan bagian bijinya dibuang. Labu kuning dikukus selama 10 menit pada suhu $80^{\circ} \mathrm{C}$. Labu kuning kemudian dipotong dengan ketebalan $2 \mathrm{~mm}$ dan dikeringkan dalam oven pada suhu $50^{\circ} \mathrm{C}$ selama 48 jam. Potongan-potongan yang telah kering dihaluskan dan diayak dengan ayakan 80 mesh. Tepung labu kuning disimpan dalam kantong plastik kedap udara untuk perlakuan selanjutnya.

\section{Ekstraksi fitokimia}

Teknik ekstraksi fitokimia menurut prosedur yang dilakukan oleh Suryanto \& Momuat (2017). Sebanyak satu gram tepung ditambahkan dengan $10 \mathrm{~mL}$ etanol $80 \%$ dan dimasukkan dalam sonikator selama 60 menit pada suhu kamar dengan frekuensi $40 \mathrm{kHz}$. Selanjutnya, sampel disaring dan disentrifugasi pada $3500 \mathrm{rpm}$ selama 10 menit. Ekstrak etanol disimpan pada suhu $5{ }^{\circ} \mathrm{C}$ untuk analisis total fenolik dan pengujian kapasitas antioksidan.

\section{Penentuan kandungan fenolik}

Kandungan total fenolik ditentukan menggunakan reagen Folin-Ciocalteu (Suryanto dkk., 2018). Sebanyak 0,1 mL larutan ekstrak sampel dimasukkan dalam tabung reaksi, kemudian ditambahkan $0,1 \mathrm{~mL}$ reagen FolinCiocalteu 50\%. Campuran divortex selama 3 menit, lalu ditambahkan larutan $\mathrm{Na}_{2} \mathrm{CO}_{3} 2 \%$ sebanyak $2 \mathrm{~mL}$. Larutan selanjutnya diinkubasi dalam ruang gelap pada suhu kamar selama 30 menit. Absorbansi diukur pada panjang gelombang $750 \quad \mathrm{~nm}$ menggunakan spektrofotometer. Hasil pembacaan absorbansi diplotkan pada kurva standar yang diperoleh 
dengan cara yang sama dengan menggunakan asam galat. Kandungan total fenol dinyatakan sebagai mg ekuivalen asam galat $/ \mathrm{kg}$ ekstrak (mg/kg Gallic Acid Equivalent).

\section{Penentuan kandungan beta karoten}

Sample tepung diekstraksi dengan menggunakan pelarut $\mathrm{PE}$ dan diukur absorbansinya menggunakan spektrofotometer pada panjang gelombang $450 \mathrm{~nm}$ (RodriguezAmaya \& Kimura, 2004). Konsentrasi karoten sebagai $\beta$-karoten dalam $\mu \mathrm{g} / \mathrm{g}$ menggunakan rumus:

$$
\beta-\text { Karotenoid }=\frac{\mathrm{A} \times \mathrm{V} \times \mathrm{D}}{\epsilon \times \mathrm{W}}
$$

Keterangan: $\mathrm{A}=$ absorbansi, $\mathrm{V}=$ volume total ekstrak, $D=$ faktor pengenceran, $\epsilon=$ koefisien absorbansi (2592 untuk PE), w= berat sampel

\section{Penentuan kapasitas penangkal radikal DPPH}

Penentuan kapasitas penangkal radikal DPPH dilakukan berdasarkan prosedur yang dilakukan oleh Li dkk. (2009) dengan sedikit modifikasi. Sebanyak 1,5 mL larutan DPPH 0,2 $\mathrm{mM}$ dalam etanol ditambahkan $0,5 \mathrm{~mL}$ ekstrak tepung komposit. Inkubasi dilakukan selama 30 menit, dan pada lima menit terakhir dari 30 menit absorbansi diukur dengan spektrofotometer pada panjang gelombang $517 \mathrm{~nm}$. Kontrol disiapkan tanpa penambahan ekstrak tepung. Aktivitas penangkal radikal bebas (KPRB) dihitung dengan menggunakan persamaan:

$$
\mathrm{KPRB}=\frac{\text { Absorbansi sampel }}{\text { Absorbansi kontrol }} \times 100 \%
$$

\section{Penentuan daya reduksi}

Penentuan daya reduksi sampel ditentukan menurut Yen dan Chen (1995). Ekstrak etanol tepung dicampur dengan buffer fosfat $(2,5 \mathrm{~mL}, 0,2$ $\mathrm{M}, \mathrm{pH} 6,6)$ dan $2,5 \mathrm{~mL}$ kalium ferisianida $1 \%$, campuran diinkubasi pada $50{ }^{\circ} \mathrm{C}$ selama 20 menit. Setelah selesai diinkubasi campuran $2,5 \mathrm{~mL}$ asam trikloroasetat ditambahkan dan divortex selama 5 menit, selanjutnya disentrifugasi pada $3000 \mathrm{rpm}$ selama 10 menit. Sebanyak $2,5 \mathrm{~mL}$ lapisan atas dari larutan tersebut ditambah dengan $2,5 \mathrm{~mL}$ akuades dan $0,5 \mathrm{~mL}$ besi (III) klorida $0,1 \%$. Peningkatan absorbansi dari campuran tersebut menunjukkan bertambahnya daya reduksi yang diukur pada panjang gelombang $700 \mathrm{~nm}$.

Formulasi tepung dan analisis data
Penelitian dilakukan dengan menggunakan metode rancangan acak lengkap satu faktor, yaitu perbandingan tepung pisang goroho dan tepung labu kuning (formulasi). Formulasi (tepung pisang goroho: tepung labu kuning) yang digunakan adalah 100\%: 0\%, 75\%: 25\%, 50\%:50\%, dan 25\% $: 75 \%$. Untuk setiap perlakuan (formulasi) dilakukan 2x ulangan sehingga diperoleh 8 satuan percobaan. Analisis ragam yang dilanjutkan dengan uji beda nyata terkecil (uji Fisher) pada taraf $5 \%$ dilakukan menggunakan software Minitab 19 trial version.

\section{HASIL DAN PEMBAHASAN}

\section{Kandungan total fenolik dan beta karoten}

Fitokimia merupakan istilah untuk berbagai senyawa yang dihasilkan secara alami oleh tanaman (phyto). Liu (2013) mendefinisikan fitokimia sebagai senyawa bioaktif (memiliki kemampuan untuk berinteraksi dengan komponen jaringan hidup) non-gizi dalam buah-buahan, sayuran, biji-bijian, dan makanan nabati lainnya yang dapat mengurangi risiko penyakit kronis yang tidak menular. Dalam penelitian ini senyawa fitokimia yang dianalisa adalah beta karoten dan total fenolik.

Analisa senyawa fitokimia dilakukan dengan bantuan sonikator pada tahap ekstraksi (ultrasound-assisted extraction/UAE). Sonikator menghasilkan gelombang ultrasonik (frekwensi > $20 \mathrm{kHz}$ ) yang selanjutnya akan merambat pada medium cair (pelarut yang digunakan) menghasilkan gelembung kavitasi. Gelembunggelembung kavitasi yang terbentuk ketika pecah (secara asimetris) dekat dengan permukaan partikel padat tersuspensi (material tanaman), akan mengha silkan gelombang kejut pelarut yang dapat merusak permukaan partikel. Gelombang kejut pelarut menghasilkan pecampuran yang efisien antara partikel tersuspensi dengan pelarut dan meningkatkan difusi komponen fitokimia dari dalam partikel tersuspensi (material tanaman) (Vinatoru dkk., 2017). Penggunaan ultrasonik dalam proses ekstraksi memberikan peningkatan hasil ekstraksi yang signifikan dengan waktu yang lebih singkat dibandingkan teknik maserasi (Saleh dkk., 2016). Spektrum absorbansi ekstrak etanol empat formulasi tepung dapat dilihat pada Gambar 1 dan spektrum absorbansi untuk ekstrak petroleum eter dapat dilihat pada Gambar 2. 


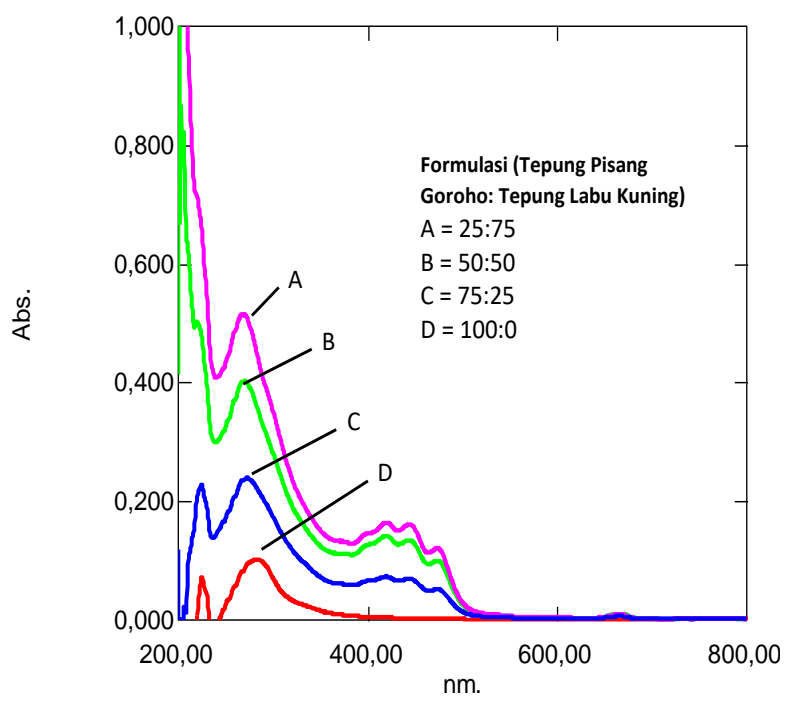

Gambar 1. Spektrum absorbansi ekstrak etanol berbagai formula tepung komposit.

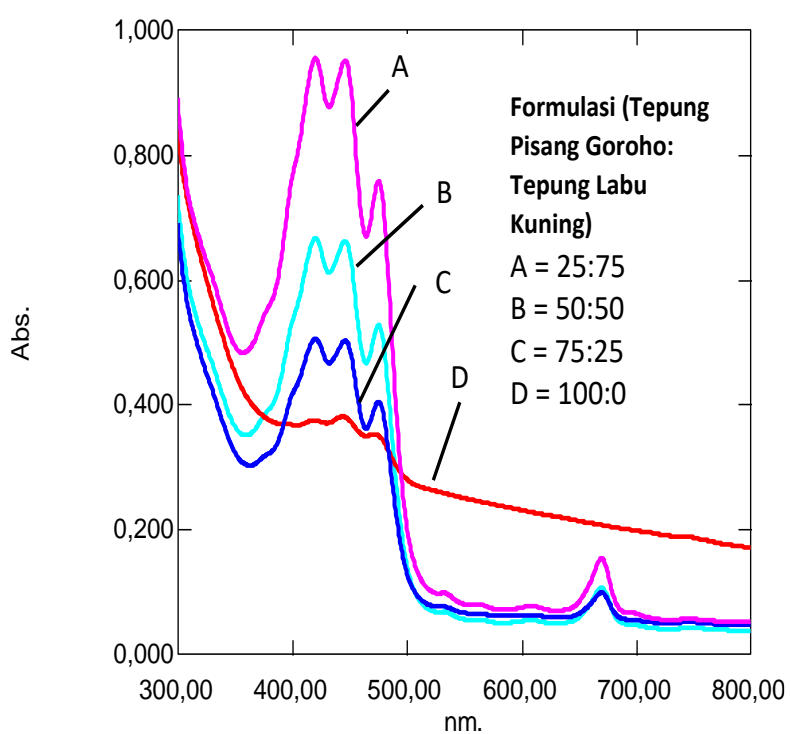

Gambar 2. Spektrum absorbansi ekstrak petroleum eter berbagai formula tepung komposit.

Kandungan fenolik pada ektrak tepung dapat dilihat pada Gambar 3. Kandungan fenolik pada ekstrak tepung meningkat dengan bertambahnya proporsi tepung labu kuning $(\mathrm{p}<0,05)$. Kandungan total fenolik pada tepung komposit berkisar antara 98,2 sampai $178,8 \mathrm{mg} / \mathrm{kg}$ GAE. Kandungan fenolik pada ekstrak tepung pisang goroho (formula 100:0) adalah yang paling rendah (60,1 mg/kg GAE). Kanopa dkk. (2012) dan Togolo dkk. (2013) juga melaporkan kandungan fenolik pada ekstrak tepung pisang goroho menggunakan teknik ekstraksi tanpa bantuan ultrasonik, masing-masing $7,04 \mathrm{mg} / \mathrm{kg}$ GAE dan $20 \mathrm{mg} / \mathrm{kg}$ GAE. Komposit dengan tepung labu kuning meningkatkan kandungan fenolik pada tepung.

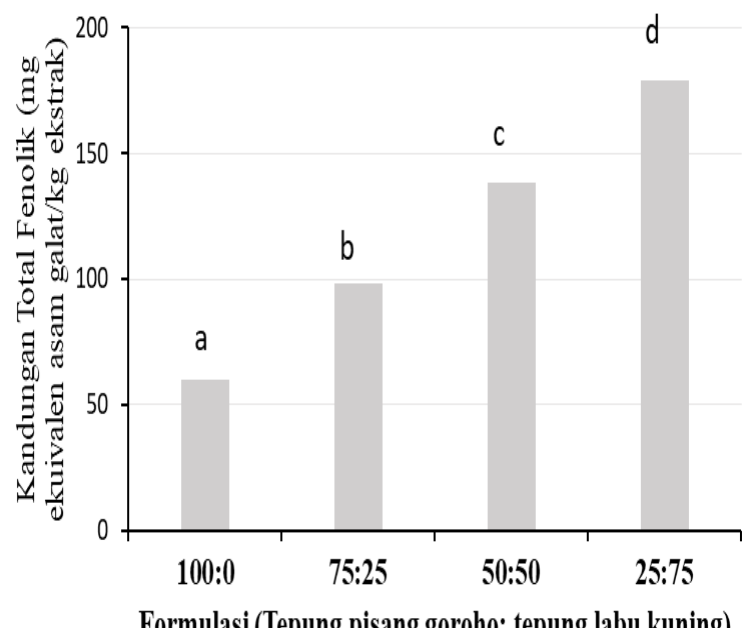

Gambar 3. Kandungan total fenolik ekstrak tepung komposit. Keterangan: Huruf yang sama menunjukkan tidak ada perbedaan nyata pada taraf nyata $5 \%$.

Hasil penelitian (Gambar 4) menunjukkan kandungan beta karoten pada tepung komposit mengalami peningkatan dengan bertambahnya proporsi tepung labu kuning $(\mathrm{p}<0,05)$. Kandungan beta karoten tepung komposit berkisar antara 186,1 sampai 497,8 $\mu \mathrm{g} / \mathrm{g}$. Berdasarkan literature, total karotenoid pada labu kuning (Cucurbita moschata) adalah $2340 \mu \mathrm{g} / \mathrm{g}$ berat bahan kering. Lutein dan beta karoten merupakan karotenoid terbanyak dengan persentasi masing-masing $39,4 \%$ dan 21,6\% dari total karotenoid (Gross, 1991).

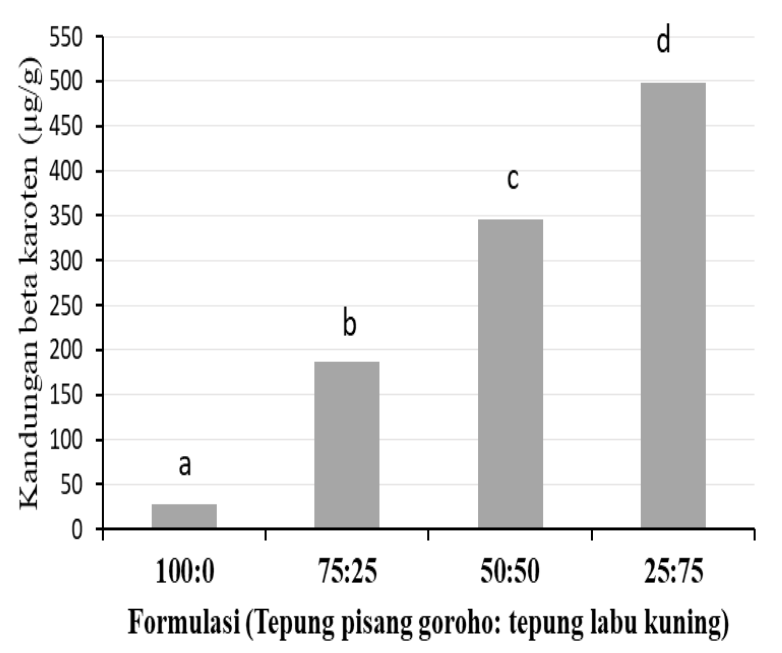

Gambar 4. Kandungan $\beta$-karoten ekstrak tepung komposit. Keterangan: Huruf yang sama menunjukkan tidak ada perbedaan nyata pada taraf nyata $5 \%$. 


\section{Kapasitas penangkal radikal bebas}

Kapasitas anti radikal dari antioksidan yang terdapat pada tepung dievaluasi dengan menggunakan radikal DPPH. Kapasitas penangkal radikal DPPH yang dihitung berdasarkan penurunan absorbansi dapat dilihat pada Gambar 5. Tepung pisang goroho (Formula 100:0) menunjukkan kapasitas penangkal radikal yang paling rendah. Peningkatan kapasitas antioksidan pada tepung komposit merupakan kontribusi dari tepung labu kuning. Hal ini dapat dilihat pada analisis fitokima yang menunjukkan peningkatan kandungan fenolik dan beta karoten dengan bertambahnya proporsi tepung labu kuning.

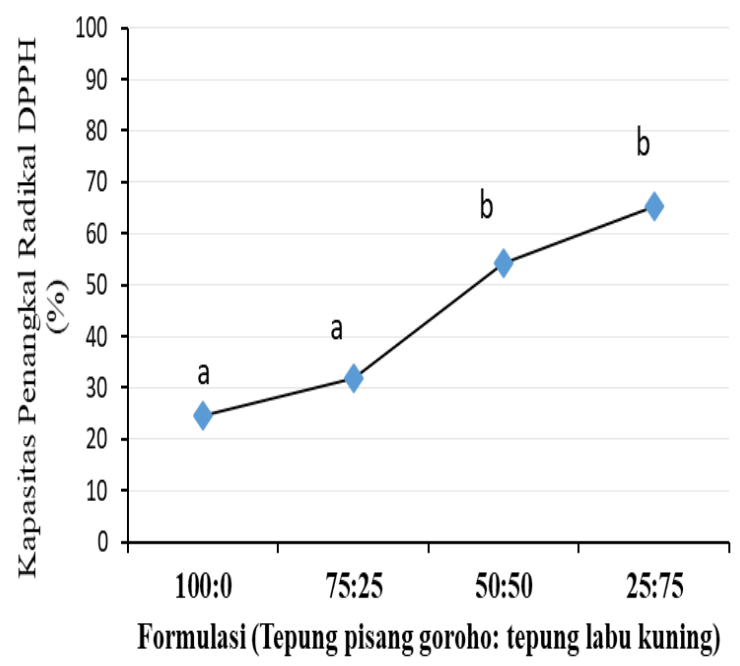

Gambar 5. Kapasitas penangkal radikal ekstrak tepung komposit. Keterangan: Huruf yang sama menunjukkan tidak ada perbedaan nyata pada taraf nyata $5 \%$.

Penurunan absorbansi pada $517 \mathrm{~nm}$ mengindikasikan penurunan radikal DPPH oleh antioksidan. Senyawa fenolik akan menyediakan atom hidrogen atau menyumbang elektron pada radikal DPPH dan mengubahnya menjadi molekul yang stabil yang menghasilkan penurunan absorbansi pada $517 \mathrm{~nm}$. Pada sebagian besar kasus, interaksi senyawa fenolik dengan radikal berlangsung melalui dua fase. Fase pertama adalah fase yang berlangsung cepat pada lima menit pertama, dan fase kedua yang berlangsung lebih lambat yang terjadi pada 25 menit selanjutnya (Molyneux, 2003). Sementara itu, karotenoid yang terpapar dengan spesies radikal akan mengalami bleaching. Proses ini terjadi karena tergangunya sistem ikatan rangkap terkonjugasi dengan pembelahan/pemutusan ikatan atau dengan penambahan pada salah satu ikatan rangkap. Menurut Mueller \& Boehm (2011), reaksi karotenoid dengan spesies radikal dapat berupa penggabungan dengan molekul radikal, transfer elektron pada molekul radikal, dan transfer hydrogen pada molekul radikal.

\section{Daya reduksi}

Daya reduksi senyawa-senyawa bioaktif berasosiasi dengan kapasitas antioksidannya. Uji daya reduksi mengukur kemampuan antioksidan dalam sampel untuk mereduksi $\mathrm{Fe}^{3+}$ (kompleks kalium ferisianida $\left[\mathrm{K}_{3} \mathrm{Fe}(\mathrm{CN}) 6\right]$ ) menjadi $\mathrm{Fe}^{2+}$ (bentuk Ferro) menurut persamaan: $\mathrm{K}_{3}\left[\mathrm{Fe}(\mathrm{CN})_{6}\right]$ $\rightarrow \mathrm{K}_{4}\left[\mathrm{Fe}(\mathrm{CN})_{6}\right]$ atau $\mathrm{Fe}^{3+}+\mathrm{e}^{-} \rightarrow \mathrm{Fe}^{2+}$ Ion $\mathrm{Fe}^{2+}$ yang terbentuk dapat diamati dengan mengukur pembentukan warna biru kehijauan pada $700 \mathrm{~nm}$. Kenaikan absorbansi pada panjang gelombang 700 $\mathrm{nm}$ menunjukkan kenaikan dalam kemampuan mereduksi (Lai dkk., 2001). Daya reduksi dari tepung dapat dilihat pada Gambar 6.

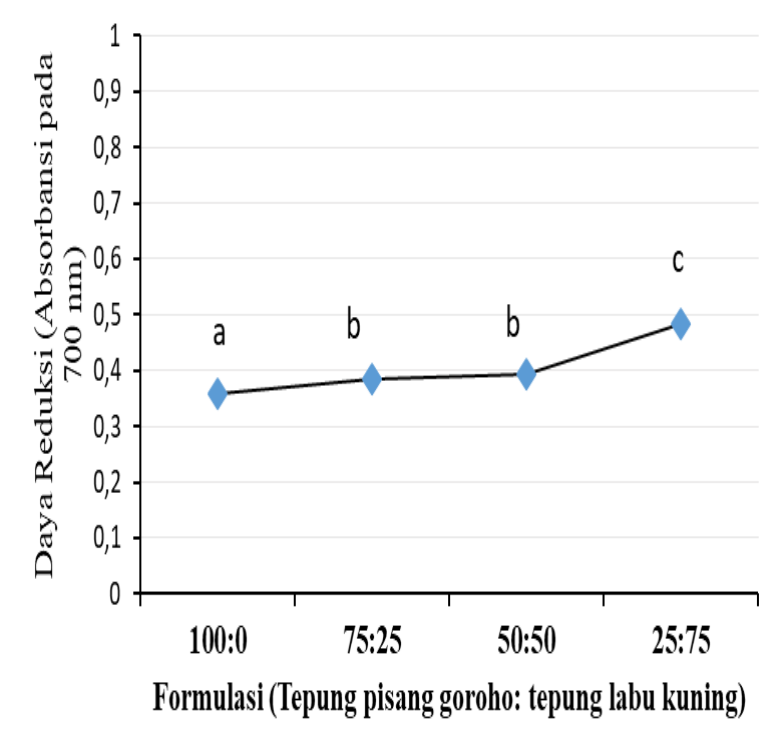

Gambar 6. Daya reduksi. Keterangan: Huruf yang sama menunjukkan tidak ada perbedaan nyata pada taraf nyata $5 \%$.

Daya reduksi tepung yang ditunjukkan dengan absorbansi pada $700 \mathrm{~nm}$ berkisar antara 0,36 sampai 0,48 . Tepung pisang goroho (Formula 100:0) memiliki daya reduksi yang paling rendah. Pada tepung komposit, peningkatan daya reduksi terjadi dengan bertambahnya proporsi tepung labu kuning. Hasil ini sesuai dengan hasil analisis fitokimia yang menunjukkan peningkatan kandungan fitokimia (fenolik dan beta karoten) pada tepung komposit dengan bertambahnya proporsi tepung labu kuning. 


\section{KESIMPULAN}

Pada tepung komposit berbasis tepung pisang goroho dan tepung labu kuning, peningkatan senyawa antioksidan (total fenolik dan beta katoren) dan kapasitas antioksidan (kemampuan menangkal radikal dan daya reduksi) terjadi dengan meningkatnya proporsi tepung labu kuning.

\section{DAFTAR PUSTAKA}

Carocho, M. \& Ferreira, I.C.F.R. 2013. A review on antioxidants, prooxidants and related controversy: natural and synthetic compounds, screening and analysis methodologies and future perspectives. Food and Chemical Toxicology. 51(1), 1525.

Falleh, H., Ksouri, R., Lucchessi, M.-E., Abdelly, C., \& Magné, C. 2012. Ultrasound-assisted extraction: Effect of extraction Time and Solvent Power on the Levels of polyphenols and antioxidant activity of mesembryanthemum edule L. Aizoaceae Shoots. Tropical Journal of Pharmaceutical Research. 11(2), 243-249.

Gross, J. 1991. Pigment in vegetables, chlorophylls and carotenoids. 1991. Springer Science Business Media. New York USA.

Gumolung, D., Suryanto, E., \& Mamuaja, C. 2013. Kapasitas antioksidan dan antifooksidasi dari ekstrak buah labu kuning (Cucurbita moschata). Jurnal Ilmu dan Teknologi Pangan. 1(1), 19401.

Kanopa, I.U., Momuat, L.I., \& Suryanto, E. 2012. Kapasitas antioksidan tepung pisang goroho (Musa spp) yang direndam dengan beberapa rempah-rempah. Jurnal MIPA UNSRAT. $1(1), 29-32$.

Lai, L.S., Chou, S.T., \& Chao, W.W. 2001. Studies on the antioxidative activities of Hsian-tsao (Mesona procumbens Hemsl) leaf gum. Journal of Agricultural and Food Chemistry. 49(2), 963-968.

Li, X., Wu, X., \& Huang, L. 2009. Correlation between antioxidant activities and phenolic contents of radix Angelicae sinensis (Danggui). Molecules. 14(12), 5349-5361.

Liu, R.H. 2003. Health benefits of fruit and vegetables are from additive and synergistic combinations of phytochemicals. American
Journal of Clinical Nutrition. 78(3), 517S$520 \mathrm{~S}$.

Liu, R.H. 2013. Health-promoting components of fruits and vegetables in the diet. Advanced Nutrition. 4 (3), 84S-92S.

Mehta, S.K., Gowder, T. \& Joghi, S. 2015. Members of antioxidant machinery and their functions.

Molyneux, P. 2003. The use of the stable free radical diphenylpicrylhydrazyl (DPPH) for estimating antioxidant activity. Songklanakarin Journal Science Technology. 26(2), 211-219.

Mueller, L. \& Boehm, V. 2011. Antioxidant activity of $\beta$-carotene compounds in different in vitro assays. Molecules. 16, 1055-1069.

Nurali, E.J.N., Djarkasi, G.S.S., Sumual, M.F.S., \& Lalujan, E.L. 2012. The potential of goroho plantain as a source of - Seafast IPB.

Pasanda, I.M., Suryanto, E., \& Djarkasi, G.S.S. 2019. Kandungan serat pangan pada tepung komposit berbasis tepung pisang goroho (Musa acuminafe,sp) dan tepung labu kuning (Cucurbita moschata). Journal Public Health Without Border. 1(1),

Prabasini, H., Ishartani, D \& Muhammad, D.R.A. 2013. Kajian sifat kimia dan fisik tepung labu kuning (Cucurbita moschata) dengan perlakuan blanching dan perendaman dalam natrium metabisulfit $\left(\mathrm{Na}_{2} \mathrm{~S}_{2} \mathrm{O}_{5}\right)$. Jurnal Teknosains Pangan. 2(2), 93-102.

Rodriguez-Amaya, D.B. \& Kimura, M. 2004. Harvestplus Handbook for Carotenoid Analysis. HarvestPlus Technical Monograph 2. Washington, DC and Cali: International Food Policy Research Institute (IFPRI) and International Center for Tropical Agriculture (CIAT).

Saleh, I. A., Vinatoru, M., Mason, T. J., AbdelAzim, N. S., Aboutabl, E. A., \& Hammouda, F. M. (2016). A possible general mechanism for ultrasound-assisted extraction (UAE) suggested from the results of UAE of chlorogenic acid from Cynara scolymus L. (artichoke) leaves. Ultrasonics Sonochemistry, 31, 330-336.

Suryanto, E. \& Momuat, L.I. 2017. Korelasi antara kapasitas antioksidan dan kandungan fenolik dari tepung komposit pisang-jagung [Prosiding]. Seminar Nasional Kimia UNY 2017. Yogyakarta 14 Oktober 2017. 
Suryanto, E., Momoat, L.I., Taroreh, M., \& Wehantouw, F. 2011. Potensi senyawa polifenol antioksidan dari pisang goroho (Musa sapien sp.). Agritech. 31(4), 289296.

Suryanto, E., Momuat, L.I., \& Wehantouw, F. 2018. Phytochemical composition and antioxidant activity of composite flour from banana, corn and sago. International Journal of ChemTech Research. 11(8), 257266.

Togolo, E., Suryanto, E., \& Sangi, M.S. 2013. Kapasitas antioksidan dari tepung pisang goroho yang direndam dengan lemon kalamansi. Jurnal MIPA UNSRAT. 2(2) 105-108.

Turang, A. 2017. Karakteristik dan Khasiat Pisang Goroho.

Vinatoru, M., Mason, T. J. \& Calinescu, I. 2017. Ultrasonically assisted extraction (UAE) and microwave assisted extraction (MAE) of functional compounds from plant materials. Trends in Analytical Chemistry, 97, 159-178.

Yen, G.C. \& Chen, H-Y. 1995. Antioxidant activity of various tea extracts in relation to their antimutagenicity. Journal of Agricultural and Food Chemistry. 43(1), 27-32. 